\title{
Laparoscopic appendectomy for perforated appendicitis in children: Is intraperitoneal drainage necessary?
}

\section{Çocuklarda perfore apandisitlerde laparoskopik apendektomi: Intraperitoneal drenaj gerekli midir?}

Mithat Günaydın, Dilek Demirel, Ferit Bernay, Ender Arıtürk, Ünal Bıçakcı, Burak Tander

\begin{abstract}
Objective: In this study, our aim is to evaluate the necessity of intraperitoneal drainage in perforated appendicitis.

Methods: 510 pediatric patients [246 laparoscopic (LA) and 264 open (OA)] underwent appendectomy between 2007 and 2014. 275 of them were perforated appendicitis (106 LA, 169 OA). The patients were retrospectively evaluated in terms of age, sex, symptoms, length of hospital stay (LOHS), antibiotherapy, postoperative nasogastric tube placement and intraperitoneal drainage, follow-up period, intraoperative and postoperative complications.
\end{abstract}

Results: Statistically significant differences were observed between laparoscopic perforated appendicitis (71 male, 35 female; median 9.5 years) and open perforated appendicitis (108 male, 61 female; median 9 years) groups in terms of placement of nasogastric tube $(102 / 106$ vs.169/169) $(p=0.021)$, length of hospital stay ( $1.67 \pm 0.11$ days vs. $2.34 \pm 0.09$ days $)(p<0.001)$, intraperitoneal drainage $(32 / 106$ vs. $138 / 169)$, $(p<0.001)$, duration of intraperitoneal drainage (1.66 \pm 0.28 vs. $4.21 \pm$ 0.2 days) and LOHS (5.82 \pm 0.3 vs. $4.23 \pm 0.6$ days) respectively $(p<0.001)$. There was no significant difference between the two groups in terms of development of intra-abdominal abscess (10/106 vs. 9/169), $(p=0.144)$, surgical site infection $(2 / 106$ vs. $8 / 169),(p=0.187)$ and development of adhesive intestinal obstruction (1/106 vs. 9/169) $(p=0.053)$.

Conclusion: Laparoscopic access reduces the necessity for drainage and shortens duration of nasogastric tube and length of hospital stay. J Clin Exp Invest 2015; 6 (3): 224-227

Key words: Laparoscopic appendectomy, perforated appendicitis, intraperitoneal drainage

\section{ÖZET}

Amaç: Bu çalışmada amacımız, perfore apandisitlerde intraperitoneal drenajın gerekliliğini değerlendirmektir.

Yöntemler: 2007-2014 yılları arasında 510 çocuk hastaya [246 laparoskopik (LA) ve 264 açık (OA] apendektomi yapıldı. Bunların 275'i perfore apandisitti (106 LA, 169 OA). Hastalar, yaş, cins, belirtiler, hastanede kalış süresi, antibiyoterapi, postoperatif nazogastrik tüp ve intraperitoneal dren, takip periyodu, intraoperatif ve postoperatif komplikasyonları açısından retrospektif olarak değerlendirildi.

Bulgular: İstatistiksel olarak, laparoskopik perfore apendektomi (71 erkek, $35 \mathrm{kız}$ ve ortanca yaş 9,5$)$ ile açık perfore apendektomi (108 erkek, $61 \mathrm{kIz}$ ve ortanca yaş 9) yapılanlar arasında nazogastrik tüp (N/G) takılması (102/106 ve 169/169), ( $p=0,021), N / G$ kalış süresi $(1,67 \pm$ $0,11$ ve $2,34 \pm 0,09$ gün $),(p<0,001)$, intraperitoneal drenin varlığı $(32 / 106$ ve 138/169), $(p<0,001)$ intraperitoneal drenajın süresi $(1,66 \pm 0,28$ ve, $4,21 \pm 0,2$ gün) $(p<0,001)$ ve hastanede kalış süresi $(5,82 \pm 0,3$ ve $4,23 \pm 0,6$ gün), $(p<0,001)$, yönüyle anlamlı farklılıklar gözlendi $(p<0,05)$. İntraabdominal abse $(10 / 106$ ve $9 / 169)(p=0,144)$ cerrahi alan enfeksiyonu $(2 / 106$ ve $8 / 169)(p=0,187)$ ve adheziv intestinal obstrüksiyon (1/106 ve 9/169) yönüyle istatistiksel olarak anlamlı fark yoktu $(p=0,053)$.

Sonuç: Laparoskopik girişim, drenaj gereksinimini azaltır, N/G tüp ve hastanede kalış süresini kısaltır.

Anahtar kelimeler: Laparoskopik apendektomi, perfore apandisit, intraperitoneal dren 


\section{INTRODUCTION}

Appendicitis is one of the most common cause of abdominal pain and is the most frequent condition necessitating emergent abdominal surgery in children [1]. With the advances in laparoscopic surgery, laparoscopic appendectomy has become the surgical procedure of choice in the treatment of acute appendicitis in the last twenty years [2]. Currently, appendectomy can be performed laparoscopically in perforated appendicitis cases as well. However, best way of management in terms of performing open or laparoscopic approach, is still controversial. While some authors reports shorter length of hospital stay and lower surgical site infection and complication rates in perforated appendicitis with laparoscopic appendectomy, others report no significant difference between laparoscopic and open approach [3,4]. Whether perforated appendicitis requires peritoneal drainage is also controversial $[5,6]$.

In this study, patients with perforated appendicitis who underwent laparoscopic appendectomy were retrospectively evaluated and compared with open surgery. The necessity of intraperitoneal drainage is evaluated as well.

\section{METHODS}

Of the 510 patients (246 laparoscopic appendectomies (LA) and 264 open appendectomies (OA)) who underwent appendectomy between 2007 and 2014,275 patients with perforated appendicitis (106 LA, 169 OA) are included in the study. The patients are retrospectively evaluated in terms of age, sex, symptoms, length of hospital stay (LOHS), antibiotherapy, duration of postoperative nasogastric (NG) tube drainage and intraperitoneal drainage (ID), follow-up period and postoperative complications. Data is extracted from patients' charts retrospectively and statistical analysis are performed by using SPSS statistical software (15.0). A $p<0.05$ value is considered statistically significant.

\section{RESULTS}

Age of the patients with laparoscopic appendectomy (LA) ranged from 3 to 17 years (median 9.5 years). Of these patients, $71(67 \%)$ were male and $35(33 \%)$ were female. In open appendectomy (OA) group, age of the patients ranged from 2 to 17 years (median 9 years). Among these, 108 (64\%) were male and $61(36 \%)$ were female. There was no sta- tistically significant difference between LA and OA groups in terms of age and sex distribution.

Abdominal pain was the most common symptom on admission. All patients received intravenous broad spectrum antibiotics. A nasogastric tube was placed peroperatively in all patients except 4 patients in the LA group. Statistically significant difference was observed between two groups in terms of NG tube placement $(p=0.021)$. Average NG tube duration was $1.67 \pm 0.11$ days in LA group and 2.34 \pm 0.09 days in OA group. The difference was statistically significant between two groups $(p<0.001)$. ID was performed in $32(30 \%)$ patients in LA group and in 138 patients $(82 \%)$ in OA group. The difference was statistically significant $(p<0.001)$. The average drainage duration was $1.66 \pm 0.28$ and $4.21 \pm 0.2$ days in LA and OA groups, respectively. No drainage was performed in the laparoscopic cases in the last two years. The difference between two groups in terms of drainage duration is statistically significant $(p<0.001)$.

The average LOHS in LA and OA groups were $5.82 \pm 0.3$ and $4.23 \pm 0.6$ days, respectively with a significant difference $(p<0.001)$. Abdominal ultrasonography was performed in patients with postoperative fever and revealed abdominal abscess in 10 (9\%) patients in LA group and $9(5.3 \%)$ patients in OA group. No statistically significant difference was observed between two groups in terms of development of intra-abdominal abscess ( $p=0.144)$.

Among the patients with intra-peritoneal abscess, one patient in the LA group required percutaneous drainage by ultrasound guidance and other have resolved with antibiotherapy alone. Among the patients with intra-abdominal abscess development, 5 patients in the laparoscopy group and all patients in the OA group had already drainage tubes placed. In LA group, 2 patients (1.8\%) developed surgical site infection (one in drainage insertion site, the other in trocar insertion site). Eight (4.7\%) patients in OA group developed surgical site infection. No statistically significant difference was observed between the groups in terms of surgical site infection ( $p=0.187$ ). One patient in laparoscopy group is converted to open surgery due to technical reasons. The conversion rate was less than $1 \%$. One patient underwent laparotomy due to postoperative adhesive intestinal obstruction. Intraperitoneal drainage have been performed in this patient during the initial procedure.

Re-operation rates were less than $1 \%$ in the laparoscopic appendectomy group. In the open ap- 
pendectomy group, nine patients have re-admitted due to postoperative adhesive intestinal obstruction and $8(4.7 \%)$ patients required re-operation. No statistically significant difference was observed between the two groups in terms of development of adhesive intestinal obstruction $(p=0.053)$. No complication was observed during the long-term followup in the laparoscopic surgery group.

\section{DISCUSSION}

Currently, minimally invasive surgery has been widely accepted in pediatric surgery. Laparoscopic appendectomy provides less postoperative pain, shorter LOHS, better cosmetics and lower complication and surgical site infection rates in the management of acute appendicitis [7]. Perforated appendicitis in childhood occurs mostly due to the delays in hospital admission and improper management of abdominal pain. Open surgery is a well-accepted procedure for the management of appendicitis [8]. However, with the increased experience of the surgeons on minimally invasive techniques, appendectomy can be performed laparoscopically in perforated appendicitis cases as well [9]. In our series, the conversion rate for laparoscopic appendectomy is less than $1 \%$. Surgery is completed laparoscopically in all the others. Although some authors have considered laparoscopy a relative contraindication for perforated appendicitis, there are several reports indicating the superiority of laparoscopic appendectomy in perforated appendicitis $[10,11]$.

As in open surgery, there is no age limit in laparoscopy in pediatric patients. In our study, the mean age of the patients are comparable between the groups. Significant difference is observed between two groups in terms of the placement and duration of NG tube drainage. This can be considered as one of the advantages of laparoscopic approach in the postoperative period.

Surgical site infection and intra-abdominal abscess are the most common complications encountered in patients with perforated appendicitis [10]. When compared with open surgery, surgical site infection rates in perforated appendicitis cases were lower in laparoscopic surgery [11]. Since open surgical technique requires a larger incision, wound infection is more likely in perforated appendicitis. In our series, wound infection rate is $1.8 \%$ in laparoscopic group while it is $4.7 \%$ in the open surgery group. However, this difference is not statistically significant. This might be attributed to the relatively small study group.
Many surgeons prefer intraperitoneal drainage to prevent the development of postoperative intraabdominal abscess. In open surgery, the entire intraperitoneal cavity cannot be adequately assessed and peritoneal space can not be washed adequately and the surgeon feel uncomfortable to not to place a drainage tube. On the other hand, laparoscopy enables the evaluation of the entire intraperitoneal cavity and cleaning the peritoneal space, thus the postoperative peritoneal drainage would be unnecessary [12].

In our cases, ID is placed in $30 \%$ of the patients in the laparoscopy group and in $82 \%$ of the patients in the open group. Statistically significant differences is found between two groups in terms of necessity of drainage. Duration of drainage was significantly shorter in the laparoscopic group. In the last two years of our seven-years study period, no drainage is performed in any of the patients who received laparoscopic appendectomy for perforated appendicitis $(n=26)$. Among these patients, intraabdominal abscess is encountered only in one patient. Increased experience and good outcome of previous patients without drains led us not to place drains in perforated appendicitis cases within last two years. According to our results, intraperitoneal drainage prolongs the LOHS and increases the morbidity without any improving effect on the development of postoperative complications and intraperitoneal drainage does not seem to be necessary in perforated appendicitis managed by laparoscopic appendectomy. Antibiotherapy is the first line treatment modality for postoperative intra-abdominal abscess. In our study, intraperitoneal abscess has developed in $5.3 \%$ of laparoscopic and $9 \%$ of open surgery cases but this difference is not found statistically significant. All of these patients has been managed with antibiotherapy alone, except one patient that required percutaneous tube drainage. On the other hand, as suggested by Clark et al, postoperative intraperitoneal abscess can also be drained laparoscopically [13].

Although there is a significant difference between the groups with respect to LOHS in favor of open surgery, mean LOHS in open surgery group is only one day shorter than the LA group. Considering the advantages of laparoscopy, this difference can be considered clinically insignificant.

No significant difference is found between laparoscopic and open group with respect to surgical site infection and development of intraperitoneal abscess for the management of perforated appendicitis in children. NG tube drainage was terminated 
after the content turned to gastric juice and/or the patient's fart. Intraperitoneal drain was removed after the drainage ceased and/or turned to serous characteristic. The duration of NG tube drainage and ID are significantly shorter in the laparoscopic group. An ID does not seem to reduce the rate of postoperative intraperitoneal abscess and complications in perforated appendicitis when managed by laparoscopic appendectomy.

In conclusion, laparoscopic appendectomy was a safe and effective procedure in children with perforated appendicitis with lower complication and re-operation rates. Laparoscopic approach reduced the necessity of intraperitoneal drainage and shortens the duration of NG drainage and LOHS as well. All pediatric perforated appendicitis cases can be managed laparoscopically in experienced hands.

\section{REFERENCES}

1. Whisker L, Luke D, Hendrickse C, et al. Appendicitis in children: a comparative study between a specialist paediatric centre and a district general hospital. J Pediatr Surg 2009; 44:362-367.

2. Ruffolo C, Fiorot A, Pagura G, et al. Acute appendicitis: What is the gold standard of treatment? World J Gastroenterol 2013;19:8799-8807.

3. Krisher SL, Browne A, Dibbins A, et al. Intraabdominal abscess after laparoscopic appendectomy for perforated appendicitis. Arch Surg 2001;136:438-441.

4. Pokala N, Sadhasivam S, Kiran RP, et al. Complicated appendicitis is the laparoscopic approach appropriate. A comparative study with the open approach: Outcome in a community hospital setting? Am Surg 2007;73:737-741.
5. Tander B, Pektaş O, Bulut M. The utility of peritoneal drains in children with uncomplicated perforated appendicitis. Pediatr Surg Int 2003;19:548-550.

6. Petrowsky H, Demartines N, Rousson V, et al. Evidence-based value of prophylactic drainage in gastrointestinal surgery: a systematic review and metaanalysis. Ann Surg 2004; 240:1074-1085.

7. Bicakci U, Tander B, Gunaydin M, et al. The Comparison of open and laparoscopic appendectomy: is there any outcome difference between non-complicated and complicated appendicitis? Balkan Med J 2011; 28:304-306.

8. Mohamed AA, Mahren KM. Laparoscopic appendectomy in complicated appendicitis: Is it safe? J Minim Access Surg 2013;9:55-58.

9. Ionescu S, Andrei B, Liscsandru E, et al. Laparoscopic treatment for complicated acute appendicitis in children, junior athletes. Chirurgia 2014;109:514-517.

10. Nataraja RM, Teague WJ, Galea J, et al. Comparision of intraabdominal abcess formation after laparoscopic and open appendicectomies in children. J Pediatr Surg 2012;47:317-321.

11. Hussain A, Mahmood H, Nicholls J, et al. Prevention of intra-abdominal abscess following laparoscopic appendicectomy for perforated appendicitis: A prospective study. Int J Surg 2008;6:374-377.

12. Cueto J, D'Allemagne B, Vazquez-Frias JA, et al. Morbidity of laparoscopic surgery for complicated appendicitis: An international study. Surg Endosc 2006;20:717-720.

13. Clark JJ, Johnson SM. Laparoscopic drainage of intraabdominal abscess after appendectomy: an alternative to laparotomy in cases not amenable to percutaneous drainage. J Pediatr Surg 2011;46:1385-1389. 